\title{
Impact of posttraumatic growth on the quality of life in woman with breast cancer
}

\author{
Suharda Chabirah ${ }^{1}$, Emmi Bujawati $^{2}$, Habibi $^{3}$, Azriful $^{4}$ \\ ${ }^{1,2,3,4}$ Bagian Epidemiologi Universitas Islam Negeri Alauddin
}

\begin{abstract}
Cancer is an abnormal cell condition that can grow faster than usual condition which makes it difficult to control. Posttraumatic Growth is a reactive psychopathological response to traumatic events. Someone who has been diagnosed with breast cancer will experience physical, psychological, and social change as well as difficulties in both sexual and daily activities. This situation is going to be affect the quality of life of patients. This study aims to look at the relationship of posttraumatic growth and the quality of life of breast cancer patients in Makassar general hospital (RSUD). This research was quantitative research with an observational analytic approach and cross-sectional study design. The research site was in RSUD Makassar. The sampling technique used was a total sampling technique in which 34 respondents were selected. The Chi-Square test results confirmed that there were significant influences of factors such as social relationship new opportunities internal strength spiritual development the expected life value and posttraumatic growth on the quality of life of patients with Ca. Mammae. Therefore, for further research in the similar scope, it is expected for future researchers to conduct research in diverse cultural settings or by adding other psychological perspectives to be discussed in the research.
\end{abstract}

Keyword: quality of life; breast cancer; posttraumatic growth

\begin{abstract}
ABSTRAK
Kanker ialah kondisi sel yang abnormal, sehingga mengalami pertumbuhan yang lebih cepat dari biasanya dan tidak terkendali. Posttraumatic Growth merupakan respon psikopatologis reaktif terhadap peristiwa traumatis. Seseorang dengan riwayat kanker payudara akan mengalami gangguan psikologis, fisik, fungsi sosial, seksual serta kehidupannya setiap saat. Hal ini akan berpengaruh terhadap kualitas hidup penderita. Penelitian ini bertujuan untuk melihat hubungan posttraumatic growth terhadap kualitas hidup pasien kanker payudara di RSUD Kota Makassar dengan jenis penelitian kuantitatif pendekatan analitik observasional dengan metode cross sectional. Lokasi penelitian yakni di RSUD Kota Makassar. Total sampling dalam penelitian ini bagian dari teknik pemilihan sampel dengan jumlah responden sebanyak 34 orang. Hasil uji Chi-Square memaparkan bahwa terdapat hubunganyang signifikan antara hubungan dengan orang lain, peluang baru, kekuatan dalam diri, pengembangan spiritual, penghargaan terhadap hidup, posttraumatic growth, terhadap kualitas hidup pasien Ca. Mammae. Dengan ruang lingkup yang sama kami mengharapakan untuk penelitian selanjutnya agar menggunakan setting budaya yang beragam maupun menambahkan perspektif psikologis lainnya.
\end{abstract}

Kata kunci: kualitas hidup; kanker payudara; posttraumatic growth

\section{PENDAHULUAN}

Kanker payudara merupakan salah satu jenis penyakit kanker yang bagi perempuan menjadi jenis kanker yang sangat menakutkan di seluruh dunia maupun di Indonesia. Kanker payudara adalah suatu penyakit neoplasma ganas di mana pertum- buhan jaringan payudara yang abnormal dibandingkan jaringan sekitarnya. Kanker ini menjadi pembunuh nomor dua setelah kanker serviks dan mulai berkembang pada kelenjar susu, saluran susu, jaringan lemak serta jaringan ikat pada payudara terhadap perempuan di dunia (Manik et al., 2012). 
World Health Organization (WHO) menyatakan bahwa kanker payudara ialah kanker yang paling umum diderita oleh perempuan baik di negara maju maupun di negara berkembang. Survei yang dilakukan WHO menyatakan $8-9 \%$ perempuan mengalami kanker payudara dan diperkirakan akan meningkat setiap tahunnya mencapai 23,6 juta kasus baru per tahun pada 2030 . Tiap tahunnya di Amerika terdapat kurang lebih 175.000 kasus, di Eropa terdiagnosa lebih dari 250.000 kasus baru dan tahun 2000 lebih dari 700.000 meninggal di perkirakan diantaranya terdapat 1,2 juta wanita terdiagnosis kanker payudara (World Health Organization, 2016).

Data di Indonesia menunjukkan kanker payudara di tahun 2007 menempati urutan pertama dengan jumlah pasien rawat inap yakni sebesar $16,85 \%$ dan pasien rawat jalan sebesar 21,69\%. Kemudiam sebanyak 39.381 kasus baru kanker payudara dan 20.052 kematian akibat kanker payudara ditemukan pada tahun 2008. Penyakit ini juga dapat diderita pada laki-laki dengan frekuensi sekitar 1\%, sedangkan prevalensi kanker payudara sebesar 12 per 100.000 perempuan (Mulyasari et al., 2017).

Berdasarkan prevalensi kanker pada semua umur di Indonesia, Provinsi Sulawesi Selatan menempati posisi ke 9 dengan persentase sebanyak $1,7 \%$ kasus kanker di tahun 2013. Untuk kasus kanker payudara di
Provinsi Sulawesi Selatan berdasarkan hasil Riskesdas 2013, tercatat sebanyak 2.975 kasus (Kementrian Kesehatan RI, 2013). Berdasarkan data perbandingan di 3 rumah sakit umum daerah yang ada di Sulawesi Selatan, yakni RSUD H. Andi Sulthan Daeng Radja Kabupaten Bulukumba berdasarkan data pasien pasca operasi kanker payudara untuk tahun 2015 sebanyak 135 pasien, untuk tahun 2016 sebanyak 92 pasien dan untuk tahun 2017 sebanyak 62 pasien. RSUD H. Padjonga Daeng Ngalle Kabupaten Takalar berdasarkan data pasien pasca operasi kanker payudara untuk tahun 2016 sebanyak 97 pasien dan untuk tahun 2017 sebanyak 81 pasien. Sedangkan RSUD Kota Makassar berdasarkan data pasien pasca operasi kanker payudara untuk tahun 2016 yaitu 46 pasien, sebanyak 117 pasien ditahun 2017, untuk tahun 2018 sebanyak 70 pasien dan pada tahun 2019 bulan Januari - April sebanyak 20 pasien.

Posttraumatic Growth (PTG) merupakan respon psikopatologis reaktif terhadap peristiwa traumatis. PTG dipengaruhi oleh beberapa faktor yang merupakan pendorong apakah pencapaian PTG ini berhasil atau tidak. Di mana faktor eksternal termasuk di dalamnya tingkat tekanan dari trauma, dukungan sosial dan pengaruh sosiokultural. Sedangkan faktor internal termasuk di dalamnya karakter personal, manajemen distress, gaya koping dan pengungkapan emosi 
diri. (Teixeira \& Pereira, 2013).

Orang yang didiagnosa menderita kanker payudara akan mengalami perubahan pada aktifitasnya sehari-hari. Hal ini akan berpengaruh terhadap quality of life (QOL) penderita (Victor et al., 2016).

Menyadari besarnya peran aspek psikologis dalam memberikan dukungan terhadap proses perawatan dan pemulihan kanker, kami memandang perlu untuk membahas lebih jauh bagaimana dinamika posttraumatic growth terhadap kualitas hidup penderita kanker payudara pasca operasi yang mengalami trauma akibat penyakit yang dideritanya. Tujuan penelitian ini adalah untuk mengetahui apakah posttraumatic growth berpengaruh pada terhadap kualitas hidup pasien kanker payudara yang berada di Rumah Sakit Makassar

\section{METODE PENELITIAN}

Jenis penelitian ini ialah analitik observasional, mengunakan pendekatan cross sectional, dengan tujuan untuk mengetahui hubungan posttraumatic growth terhadap kualitas hidup pasien ca. mammae di RSUD Kota Makassar. Sampel dalam penelitian ini diperoleh dengan menggunakan teknik total sampling, yaitu sebanyak 34 sampel. Analisis data yang digunakan adalah analisis univariat serta bivariat untuk mendapatkan deskripsi umum dengan menggambarkan dan melihat hubungan antara variabel dependen serta independen dengan menggunakan analisis uji chi-square.

\section{HASIL PENELITIAN}

Berdasarkan tabel 1 menunjukkan bahwa dari 34 responden, kualitas hidup yang sama anatara kategori baik dan kategori kurang. Hubungan dengan orang lain dengan kategori baik sama dengan kategori buruk. Peluang baru dengan kategori baik adalah (64,7\%) sedangkan kategori buruk adalah (35,3\%). Kekuatan dalam diri dengan kategori baik adalah (76,5\%) sedangkan kategori buruk adalah (23,5\%). Pengembangan spiritual dengan kategori baik adalah (76,5\%) sedangkan kategori buruk adalah $(23,5 \%)$. Penghargaan terhadap hidup dengan kategori baik adalah (76,5\%) sedangkan kategori buruk adalah $(23,5 \%)$. Sedangkan pada posttraumatic growth dengan kategori positif sama dengan kategori negatif.

Berdasarkan tabel 2 menunjukkan bahwa terdapat hubungan antara hubungan dengan orang lain $(p=0,006)$, peluang baru $(p=0,001)$, kekuatan dalam diri $(p=0,040)$, pengembangan spiritual $(p=0,043)$, penghargaan terhadap hidup $(\mathrm{p}=0,043)$, posttraumatic growth $(p=0,006)$ terhadap kualitas hidup pasien Ca. Mammae. 


\section{PEMBAHASAN}

Penyajian pembahasan pada penelitian ini yaitu dalam bentuk narasi dari hasil penelitian yang dilakukan oleh peneliti. Tujuan penelitian pada setiap variabel akan dibahas yang terdiri dari hubungan dengan orang lain, peluang baru, kekuatan dalam diri, pengembangan spiritual,penghagaan terhadap hidup, dan posttraumatic growth terhadap kualitas hidup pasien Ca. Mammae di RSUD Kota Makassar. informasi, mengekspresian perasaan serta meningkatkan kemampuan koping individu. Manfaat lain yang diperoleh bagi penderita yaitu meningkatnya semangat hidup dan tingkat spiritual meningkat. Penderita dapat meningkatkan kualitas hidupnya diantaranya nafsu makan meningkat dan tidak ada gangguan tidur.

Berdasarkan hasil penelitian, terdapat hubungan antara hubungan dengan orang lain terhadap kualitas hidup pasien $\mathrm{Ca}$.

Tabel 1. Analisis Univariat Posttraumatic Growth Terhadap Kualitas Hidup Pasien Ca. Mammae

\begin{tabular}{|c|c|c|c|}
\hline \multicolumn{2}{|c|}{ Variabel } & \multirow{2}{*}{$\frac{\text { Frekuensi (n) }}{17}$} & \multirow{2}{*}{$\frac{\text { Persentase }(\%)}{50}$} \\
\hline$Y$ ulito Lidu & Baik & & \\
\hline nuamtas hiaup & Buruk & 17 & 50 \\
\hline \multirow{2}{*}{ Hubungan Dengan Orang Lain } & Baik & 17 & 50 \\
\hline & Buruk & 17 & 50 \\
\hline \multirow{2}{*}{ Peluang Baru } & Baik & 22 & 64,7 \\
\hline & Buruk & 12 & 35,3 \\
\hline \multirow{2}{*}{ Kekuatan Dalam Diri } & Baik & 26 & 76,5 \\
\hline & Buruk & 8 & 23,5 \\
\hline \multirow{2}{*}{ Pengembangan spiritual } & Baik & 26 & 76,5 \\
\hline & Buruk & 8 & 23,5 \\
\hline \multirow{2}{*}{ Penghargaan Terhadap Hidup } & Baik & 26 & 76,5 \\
\hline & Buruk & 8 & 23,5 \\
\hline \multirow{2}{*}{ Posttraumatic growth } & Positif & 17 & 50 \\
\hline & Negatif & 17 & 50 \\
\hline
\end{tabular}

Sumber: Data Primer, 2019

Manusia sebagai mahluk sosial untuk memenuhi kebutuhan dalam hidupnya selalu membutuhkan orang lain, salah satunya adalah dukungan sosial. Konsep dukungan sosial melibatkan adanya komunikasi antar kelompok. Penderita kanker payudara yang meiliki support group dapat saling bertukar
Mammae di RSUD Kota Makassar dengan nilai $(p=0,006)$, hal ini disebabkan karena terbentuknya hubungan sosial yang baik terhadap penderita kanker akan membuat mereka dapat beradaptasi secara lebih baik dengan penyakitnya. Selain itu, dalam memperbaiki status kesehatan seseorang, 
maka dukungan sosial juga mempunyai peran penting

Hasil penelitian ini didukung oleh penelitian Sari (2016) pada wanita yang terkena kanker payudara dengan 2 kelompok, yaitu pada ibu rumah tangga maupun karyawati. Penelitian ini mengemukakan bahwa kedua kelompok tersebut merasakan manfaat positif dukungan sosial terhadap semangat kesembuhan mereka. Adanya dukungan sosial dari teman maupun keluarga mampu menghilangkan tekanan psikologis, stigma negatif, putus asa, kesedihan dan merasa antusias menjalani pengobatan kanker payudara.

New possibilities (peluang baru) ialah identifikasi pada individu tentang kemungkinan adanya peluang baru dalam kehidupannya atau kemungkinan untuk meraih pola kehidupan yang berbeda dan baru. Beberapa orang dapat memperlihatkan ketertarikan pada hal baru, serta menjalani aktivitas kehidupan yang baru serta signifikan.

Berdasarkan data tersebut ada hubungan antara peluang baru terhadap kualitas hiduo pasien Ca. Mammae di RSUD Kota Makassar dengan nilai $(p=0,001)$. Penelitian ini sejalan dengan penelitian yang dilakukan oleh Mawaddah (2018) mengenai posttraumatic growth pada wanita dewasa madya penderita kanker payudara di mana hasil penelitian ini menunjukkan adanya peluang baru dalam kehidupan seseorang pasca tertimpa musibah.

Hasil penelitian ini sejalan dengan penelitian yang dilakukan oleh Rachmawati \& Halimah (2015) yang menyatakan bahwa perubahan pada faktor new possibilities ini ditandai dengan identivikasi individu terhadap kemungkinan baru dalam hidupnya bahkan menentukan tujuan baru dalam kehidupannya. Setelah proses berjuang dalam menghadapi kesulitan, penderita mampu menemukan pilihan baru untuk hidupnya di beberapa domain. Penciptaan jalan hidup yang baru terkait dengan persepsi filosofi hidup yang baru dari asumsi masa lalu dan keyakinan yang mengarah pada kemungkinan dan peluang yang akan ada atau yang tidak terpikirkan sebelum trauma.

Kekuatan dalam diri tidak berkaitan dengan kemampuan sebenarnya melainan keyakinan yang dimiliki individu. Kekuatan dalam diri pada pasien kanker berfokus pada keyakinan yang dimiliki terhadap kemampuannya untuk melakukan berbagai perilaku perawatan diri atau selfmanagement. Hal ini diperkuat dengan penelitian yang menyebutkan bahwa kekuatan dalam diri mempunyai hubungan positif dengan perilaku perawatan diri yang pada akhirnya akan meningkatkan kualitas hidup pasien (Mawaddah, 2018). 
Berdasarkan hasil penelitian tersebut ada hubungan antara kekuatan dalam diri terhadap kualitas hidup pasien Ca. Mammae di RSUD Kota Makassar dengan nilai $(p=0,040)$ karena terdapat positive improvement in life terhadap subjek penelitian tersebut, di mana dalam menjalankan aktivitas menuju ke level yang lebih baik. Pada aspek ini seseorang semakin mengenal kekuatan dalam dirinya.

Religiusitas merupakan sifat lahirnya kemauan dalam hati untuk melakukan hubungan kepada Allah SWT. Kehidupan adalah jalan yang harus dijalani setiap individu

Tabel 2. Analisis Biivariat Posttraumatic Growth Terhadap Kualitas Hidup Pasien Ca. Mammae

\begin{tabular}{|c|c|c|c|c|c|c|c|c|c|}
\hline \multirow{3}{*}{ Variabel } & & \multicolumn{4}{|c|}{ Kualitas Hidup } & \multirow{2}{*}{\multicolumn{2}{|c|}{ Total }} & \multirow{3}{*}{$\begin{array}{c}\mathrm{P}- \\
\text { value }\end{array}$} & \multirow{3}{*}{$\mathrm{RP}$} \\
\hline & & \multicolumn{2}{|c|}{ Baik } & \multicolumn{2}{|c|}{ Buruk } & & & & \\
\hline & & $\mathrm{n}$ & $\%$ & $\mathrm{n}$ & $\%$ & $\mathrm{~N}$ & $\%$ & & \\
\hline \multirow{2}{*}{ Hubungan Dengan Orang } & Baik & 13 & 38,2 & 4 & 11,8 & 17 & 50 & \multirow{2}{*}{0,006} & \multirow{2}{*}{3,3} \\
\hline & Buruk & 4 & 11,8 & 13 & 38,2 & 17 & 50 & & \\
\hline \multirow{2}{*}{ Peluang Baru } & Baik & 16 & 47 & 6 & 17,6 & 22 & 64,6 & \multirow{2}{*}{0,001} & \multirow{2}{*}{9} \\
\hline & Buruk & 1 & 3 & 11 & 32,4 & 12 & 35,4 & & \\
\hline \multirow{2}{*}{ Kekuatan Dalam DIri } & Baik & 16 & 47 & 11 & 32,2 & 27 & 79,3 & \multirow{2}{*}{0,040} & \multirow{2}{*}{4,2} \\
\hline & Buruk & 1 & 3 & 6 & 17,7 & 7 & 20,7 & & \\
\hline \multirow{2}{*}{ Penembangan Spiritual } & Baik & 16 & 47 & 10 & 29,4 & 26 & 85,3 & \multirow{2}{*}{0,043} & \multirow{2}{*}{4,7} \\
\hline & Buruk & 1 & 3 & 7 & 20,6 & 8 & 14,7 & & \\
\hline \multirow{2}{*}{$\begin{array}{l}\text { Penghargaan Terhadap } \\
\text { Hidup }\end{array}$} & Baik & 16 & 47 & 10 & 29,4 & 26 & 76,5 & \multirow{2}{*}{0,043} & \multirow{2}{*}{4,7} \\
\hline & Buruk & 1 & 3 & 7 & 20,6 & 8 & 23,5 & & \\
\hline \multirow{2}{*}{ Posttraumatic Growth } & Baik & 13 & 38,2 & 4 & 11,8 & 17 & 50 & \multirow{2}{*}{0,006} & \multirow{2}{*}{3,3} \\
\hline & Buruk & 4 & 11,8 & 13 & 38,2 & 17 & 50 & & \\
\hline
\end{tabular}

Sumber: Data Primer, 2019

kesehariannya subjek dalam penelitian tersebut sangat termotivasi dan bersemangat. Justru di tengah sakitnya itu, mereka semakin giat bekerja. Menurutnya, mereka merasa seolah-olah tidak mengidap penyakit kanker payudara ketika bekerja.

Penelitian ini sejalan dengan penelitian yang dilakukan oleh Mawaddah (2018) mengenai posttraumatic growth pada wanita dewasa madya penderita kanker payudara di mana hasil penelitian ini memaparkan adanya perubahan yang positif serta harus siap menghadapi segala cobaan. Bagi penderita kanker, keadaan sakit harus disikapi secara psikologis dengan lahirnya kemauan dalam hati untuk mendekatkan diri kepada Maha Memberi Cobaan, Allah swt. Hubungan tersebut dapat dilihat pada ketaatan melaksakanan apa yang diyakini sebagai perintah atau kehendak Allah. Pengaruh religiusitas terhadap kualitas hidup pasien kanker selanjutnya adalah meyakini ahwa Allah Maha Agung dan Maha Adil, sehingga pasti akan memberi balasan dan ganjaran 
sempurna pada suatu waktu yang ditentukan.

Berdasarkan hasil penelitian yaitu diperoleh ada hubungan antara pengembangan spiritual terhadap pemberian kualitas hidup pasien Ca. Mammae di RSUD Kota Makassar dengan nilai $(p=0,043)$. Agama Islam telah mengarahkan setiap individu untuk mencapai kualitas hidup secara maksimal. Setiap individu yang beragama akan melakukan ibadah sebagai sebuah kewajiban yang positif, karena jika tidak individu tersebut akan menerima hukuman dari Allah dan jika ibadah dilakukan dengan benar dan ikhlas akan menerima pahala dan surga. Semua subjek dalam penelitian tersebut memiliki perubahan kearah yang lebih baik dalam spiritualitas dan dalam beribadah kepada Allah SWT. Pasca terdiagnosa kaker payudara, semua subjek penelitian tersebut belajar mendekatkan diri lebih baik lagi dibandingkan sebelumnya, mempelajari Al-Quran beserta kandungannya dan berbuat baik sebanyak mungkin untuk bekal kembali kepada Tuhan Yang Maha Esa. Sebagaimana firmal Allah SWT dalam QS. Yunus/10 yang terjemahnya :

"Hai manusia, Sesungguhnya telah datang kepadamu pelajaran dari Tuhanmu dan penyembuh bagi penyakit-penyakit (yang berada) dalam dada dan petunjuk serta rahmat bagi orang-orang yang beriman."
Berdasarkan tafsil Al-Misbah, Shihab (2012) mengemukakan bahwa umat manusia telah diberitakan akan diturunkannya kitab kitab Allah yang disampaikan melalui utusan-Nya, Muhammad, di dalamnya terdapat peringatan untuk beriman serta bertaqwa, serta nasihat untuk menjauhi kejahatan serta melakukan kebajikan. Selain itu, di dalamnya juga terdapat kisah-kisah orang sebelum kalian agar dapat dijadikan bahan renungan dan pengamatan terhadap anjuran untuk melakukan pengamatan terhadap rahasia-rahasia alam raya, sehingga kalian dapat menyadari keagungan ciptaanNya. Disamping itu, kitab ini pun dapat mengatasi penyakit hati, semisal kemunafikan dan kemusyrikan. Kitab al-quran ini diturunkan agar menjadi pedoman untuk mendapatkan hidayah. Jika kaum mukminin menerima dengan ikhlas akan menjadi rahmat baginya

Hasil penelitian ini juga didukung oleh pernyataan Mayasari (2014) bahwa individu yang memiliki tingkat religiusitas yang tinggi lebih mampu memaknai kejadian hidupnya secara positif sehingga hidupnya menjadi lebih bermakna. Makna hidup inilah yang membuat individu mampu mengatasi tantangan dan hambatan dalam hidup karena mereka merasakan kedekatan terhadap Allah SWT.

Penghargaan terhadap hidup merupakan perubahan mengenai hal apa yang 
penting dalam hidup seseorang. Perubahan yang mendasar adalah perubahan mengenai prioritas hidup seseorang yang juga dapat meningkatkan penghargaan terhadap hal-hal yang dimilikinya.

Berdasarkan data tersebut ada hubungan antara penghargaan terhadap hidup dengan kualitas hidup pasien Ca. Mammae di RSUD Kota makassar dengan nilai $(p=0,043)$. Adapun penghargaan terhadap hidup dari yang penderita rasakan yaitu mereka lebih mampu menghargai kehidupan yang dapat mereka jalani saat ini. Hal ini sesuai dengan pernyataan (Tedeschi \& Calhoun, 2004) yaitu penghargaan terhadap hidup penderita meningkat untuk nilai kehidupan sendiri serta rasa perlu meningkatkan prioritas tentang apa yang penting dalam hidupnya.

Penelitian ini sejalan dengan penelitian yang dilakukan oleh Mawaddah (2018) mengenai posttraumatic growth pada wanita dewasa madya penderita kanker payudara di mana hasil penelitian ini menunjukkan adanya perubahan positif menuju ke level yang lebih baik. Subjek dalam penelitian tersebut merubah hidupnya menjadi lebih penting dan berharga, penghargaan terhadap kesempatan baru yang diberikan Tuhan kepada subjek dalam penelitian tersebut.

Posttraumatic growth adalah pengalaman berupa perubahan positif yang terjadi sebagai hasil dari perjuangan seseorang dalam menghadapi tantangan krisis kehidupan yang tinggi. Pada uumnya orang-orang melihat reaksi negatif yang dihasilan dari sebuah kejadian traumatik, namun Tedeschi dan Calhoun memunculkan sebuah area penelitian baru yang melihat reaksi positif yang dihasilkan dari suatu kejadian traumatik yang kemudian dikenal dengan istilah posttraumatic growth. Istilah ini menuju pada perubahan yang terjadi ada persepsi seseorang tentang kehidupannya setelah orang tersebut berjuang untuk menghadapi krisis yang terjadi.

Hasil penelitian ini menunjukkan bahwa ada hubungan antara posttraumatic growth dengan kualitas hidup pasien $\mathrm{Ca}$. Mammae di RSUD Kota makassar dengan nilai $(p=0,006)$. Individu tidak hanya sekedar kembali pada kenyataan sebelumnya, namun menggunakan trauma sebagai sebuah kesempatan untuk perkembangan diri selanjutnya. Jadi, setelah seseorang berjuang melawan krisis berat yang dihadapinya ada perubahan positif yang bisa dinikmatinya.

Penelitian ini sejalan dengan Mawaddah (2018) yang menyatakan terdapat hubungan yang signifikan antara posttraumatic growth dengan kualitas hidup dimensi fisik dan dimensi psikologis dengan signifikan korelasi yang kuat pada pasien kanker. Perubahan posttraumatic growth terbesar pada 
perubahan spiritual dan hubungan dengan sesama. Berbagai masalah yang mempengaruhi kondisi fisik pasien dapat menyebabkan berbagai masalah psikososial mengarah pada terganggunya kehidupan sehari-hari serta kualitas hidup.

\section{KESIMPULAN}

Hasil penelitian menunjukkan bahwa: Terdapat hubungan antara hubungan dengan orang lain $(p=0,006)$, peluang baru $(p=0,001)$, kekuatan dalam diri $(p=0,040)$, pengembangan spiritual $(p=0,043)$, penghargaan terhadap hidup $(p=0,043)$, posttraumatic growth $(\mathrm{p}=0,006)$ terhadap kualitas hidup pasien Ca. Mammae.

\section{SARAN}

Berdasarkan penelitian ini disarankan kepada pasien kanker payudara sebaiknya lebih mendekatkan diri kepada Allah, memandang bahwa penyakit yang dideritanya itu sebagai hikmah yang diberikan Allah kepadanya dan bukan menyalahkan Allah atas apa yang dideritanya. Keluarga maupun pasangan pasien kanker payudara bisa menerima keadaan pasien apa adanya setelah terdiagnosa kanker maupun melakukan pengangkatan payudara dengan memberikan dukungan yang lebih intens, sehingga dapat membantu mempercepat proses penyembuhan pasien kanker payudara. Menggunakan subjek penelitian dengan setting budaya yang beragam maupun menambahkan perspektif psikologis lain yang dapat diteliti untuk penelitian selanjutnya.

\section{DAFTAR PUSTAKA}

Kementrian Kesehatan RI. (2013). Riset Kesehatan Dasar 2013. https:// www.kemkes.go.id/resources/ download/general/Hasil Riskesdas 2013.pdf

Manik, N. T., Maryati, I., \& Ermiati. (2012). Riwayat Gaya Hidup Penderita Kanker Payudara Di Rumah Sakit Umum Daerah Kota Sumedang. Student E-Journal, 1(1), 1-16.

Mawaddah, L. Z. S. (2018). Posttraumatic Growth Pada Wanita Dewasa Madya Penderita Kanker Payudara [Universitas Islam Negeri Sunan Ampel]. digilib.uinsby.ac.id/26187/2/Lia

Zairoh Siska Mawaddah_J01214015.pdf

Mayasari, R. (2014). Regiliutas Islam dan Kesehatan (Sebuah Telaah dengan Perspektif Psikologi). Al-Munzir, 7 (2), 81-100. https://doi.org/http:// dx.doi.org/10.31332/am.v7i2.281

Mulyasari, A. D., Bahar, H., \& Ismail, C. S. (2017). Analisis faktor risiko kanker payudara pada RSU. Bahteramas Kota Kendari Provinsi Sulawesi Tenggara tahun 2017. JIMKESMAS: Jurnal Ilmiah Mahasiswa Kesehatan Masyarakat, 2(6), 1-10. https://doi.org/http:// dx.doi.org/10.37887/ jimkesmas.v2i6.2877

Rachmawati, N., \& Halimah, L. (2015). Studi Deskriptif Mengenai Gambaran Post Traumatic Growth (PTG) Pada 
Wanita Penderita Kanker Payudara Pasca Mastektomi Di Bandung Cancer Society (BCS). Prosiding Psikologi, 1 (2), 101-107. http:// karyailmiah.unisba.ac.id/index.php/ psikologi/article/view/1079/pdf

Sari, G. I. R. (n.d.). Hubungan Antara Kebersyukuran dengan Resiliensi Pada Penderita Penyakit Kronis.

Shihab, M. Q. (2012). Tafsir al-Mishbāh: pesan, kesan, dan keserasian alQur'an. Lentera Hati. https:// books.google.co.id/books? $\mathrm{id}=$ wKomjwEACAAJ

Tedeschi, R. G., \& Calhoun, L. G. (2004). Target Posttraumatic Growth: Conceptual Foundations and Empirical Evidence of North Carolina Charlotte circumstances. Psychological Inquiry, 15(1), 1-18. https://sites.uncc.edu/ ptgi/wp-content/uploads/ sites/9/2013/01/PTG-ConceptualFoundtns.pdf
Teixeira, R., \& Pereira, M. G. (2013). Factors Contributing to Posttraumatic Growth and Its Buffering Effect in Adult Children of Cancer Patients Undergoing Treatment. Journal of Psychosocial Oncology, 31(3), 235-265. https://

doi.org/10.1080/07347332.2013.7789 32

Victor, I. G. P., Setiaji, K., \& Wahyono, A. (2016). Faktor-faktor yang mempengaruhi kualitas hidup penderita kanker payudara stadium lanjut lokal yang dirawat sesuai protokol bedah onkologi di RSUP dr. Sardjito Yogyakarta [Universitas Gadjah Mada]. http://etd.repository.ugm.ac.id/ penelitian/detail/104181\#filepdf

World Health Organization. (2016). Comprehensive Cervical Cancer Control: A Guide to Essential Practice (2==). World Health Organization. https:// books.google.co.id/books? $\mathrm{id}=4 \mathrm{uZ} \operatorname{lrgEACAAJ}$ 